\title{
UJI KUALITAS KARBON AKTIF DARI KULIT UBI KAYU (MANIHOT ESCUENTA CRANTZ)
}

\author{
Lazulva,Wiwit Widia Sari
}

\author{
Program Studi Pendidikan Kimia, Universitas Islam Negeri SUSKA Riau \\ Email: lazoelva_1154@yahoo.com
}

\begin{abstract}
ABSTRAK
Kulit ubi kayu merupakan limbah agroindustri seperti industri tepung tapioka, industri fermentasi dan industri produk makanan. Jumlah limbah kulit ubi kayu yang cukup besar bila tidak ditangani dengan baik dan benar dikhawatirkan akan menimbulkan masalah pencemaran lingkungan. Salah satu upaya pemanfaatan limbah kulit ubi kayu yaitu dilakukan dengan mengolahnya menjadi karbon aktif. Penelitian ini bertujuan untuk mengetahui pengaruh suhu karbonisasi terhadap kualitas karbon aktif yang dihasilkan dari kulit ubi kayu dan mengetahui suhu optimum untuk mendapatkan karbon aktif dengan kualitas yang bagus. Penelitian ini dilakukan dengan menggunakan variasi suhu karbonisasi yaitu suhu $300{ }^{\circ} \mathrm{C}, 450{ }^{\circ} \mathrm{C}$ dan suhu $600{ }^{\circ} \mathrm{C}$, serta diaktivasi secara kimia dengan $\mathrm{KCl} 10 \%$. Pengujian kualitas karbon aktif dilakukan terhadap rendemen, kadar air, kadar abu, daya serap terhadap Iod dan methylene blue. Kualitas karbon aktif dari kulit ubi kayu yang paling baik adalah karbon aktif yang dikarbonisasi pada suhu $600{ }^{\circ} \mathrm{C}$ dengan hasil rendemen $16,844 \%$, kadar air 2,910 \%, kadar abu 1,920 \%, daya serap terhadap iod 792,427 $\mathrm{mg} / \mathrm{g}$ dan daya serap terhadap methylene blue $19,925 \mathrm{mg} / \mathrm{g}$.
\end{abstract}

Kata Kunci: karbon aktif, ubi kayu,

\section{PENDAHULUAN}

Limbah pertanian yang tidak termanfaatkan dapat mencemari lingkungan dan mengganggu estetika. Limbah pertanian dapat diubah menjadi arang dan karbon aktif yang kemudian dapat dimanfaatkan sebagai pengendali cemaran bahan agrokimia (pestisida dan pupuk) dan logam berat di lahan pertanian melalui ameliorasi. Berbagai hasil pertanian dan limbah pertanian yang mengandung kadar selulosa tinggi dapat digunakan sebagai bahan baku dalam pembuatan karbon aktif [1].

Bahan baku yang berasal dari hewan, tumbuh-tumbuhan, limbah ataupun mineral yang mengandung karbon dapat digunakan sebagai bahan pembuatan karbon aktif, antara lain: kayu lunak, tulang, sekam, tongkol jagung, tempurung kelapa, dan sebagainya. Menurut Jankowska, karbon aktif dapat dibuat dari biji buah-buahan, dan kulit kacang-kacangan.

Sebagai tanaman pangan, ubi kayu merupakan sumber karbohidrat bagi sekitar 500 juta manusia di dunia. Sebagai sumber karbohidrat, ubi kayu merupakan penghasil kalori terbesar dibandingkan dengan tanaman lain. Di
Indonesia ubi kayu dijadikan makanan pokok nomor tiga setelah padi dan jagung [2]. Ubi kayu merupakan makanan yang dapat diolah untuk mendapatkan suatu hasil yang lebih dapat dirasakan manfaatnya, yaitu dengan cara mengolah ubi kayu menjadi tepung tapioka, tape, kripik dan sebagainya.

Dalam pengolahannya menjadi bahan makanan manusia, kulit ubi kayu mengalami pengelupasan kulit terlebih dahulu. Dengan kata lain kulit luar ubi kayu merupakan limbah hasil pengolahan ubi kayu yang ternyata jumlahnya sangat besar. Tapi, Pemanfaatan kulit ubi kayu secara komersil masih relatif kecil. Hal ini disebabkan karena kulit ubi kayu mengandung 35 kali lebih banyak kadar asam sianida $(\mathrm{HCN})$ dari ubinya yang sangat berbahaya jika dikonsumsi oleh manusia. Disamping itu, limbah kulit ubi kayu mempunyai sifat-sifat kotor, nilai gizinya rendah, kepadatannya rendah, serta kandungan abunya cukup tinggi.

Salah satu cara untuk mengatasi limbah kulit ubi kayu tersebut adalah dengan membuatnya menjadi lebih berguna dan mempunyai nilai ekonomi yang lebih tinggi, yaitu sebagai bahan 
baku pembuatan karbon aktif. Kulit ubi kayu dapat dijadikan sebagai bahan baku karbon aktif karena mengandung selulosa yang tinggi dan karbon sebesar 59,31 dalam persen beratnya. Pembuatan karbon aktif dilakukan dengan menggunakan aktivator $\mathrm{KCl}$ dengan variasi suhu karbonisasi $300{ }^{\circ} \mathrm{C}, 450{ }^{\circ} \mathrm{C}$ dan $600{ }^{\circ} \mathrm{C}$. Suhu karbonisasi merupakan salah satu parameter yang digunakan untuk menentukan kondisi karbonisasi yang sesuai, sehingga memungkinkan kita untuk memperoleh karbon aktif dengan kualitas yang bagus dan sesuai dengan standar yang telah di tentukan.

\section{METODOLOGI PENELITIAN}

Alat

Alat-alat yang digunakan adalah labu ukur, batang pengaduk, erlenmeyer, beaker glass, desikator, corong, muffle furnace, neraca analitik, spektrofotometer UV-VIS, seperangkat alat titrasi, magnetik stirer, oven.

\section{Bahan}

Kulit ubi kayu, $\mathrm{KCl} 10 \%$, air suling, methylene blue 0, 2, 4, 6, 10 dan 100 ppm, larutan amilum $1 \%$, larutan $\mathrm{Na}_{2} \mathrm{~S}_{2} \mathrm{O}_{3} 0,1 \mathrm{~N}$, larutan iodium $0,1 \mathrm{~N}, \mathrm{HCl} 0,5 \mathrm{~N}$.

Sampel Kulit ubi kayu yang berwarna putih dibersihkan, kemudian dijemur sampai kering. Setelah itu, kulit ubi kayu tersebut dipotong kecil-kecil.

\section{Proses Aktivasi}

1500 gram kulit ubi kayu kering dikontakkan dengan larutan $\mathrm{KCl} 10 \%$ di dalam mixer (RTB) selama 1 jam pada suhu $50{ }^{\circ} \mathrm{C}$. Kemudian kulit ubi kayu ditiriskan dan dioven selama 24 jam pada suhu $120{ }^{\circ} \mathrm{C}[3]$.

\section{Proses Karbonisasi}

Kulit ubi kayu yang telah dikeringkan dengan oven,dikarbinisasi dengan furnace elektrik dan dikarbonisasi pada suhu (T) yaitu $300^{\circ} \mathrm{C}, 450^{\circ} \mathrm{C}$, dan $600^{\circ} \mathrm{C}$. Kecepatan kenaikan suhu furnace sebesar $10^{\circ} \mathrm{C} /$ menit dari suhu ruangan (berkisar $29{ }^{\circ} \mathrm{C}$ ) sampai suhu yang diinginkan tercapai. Lamanya waktu (t) karbonisasi adalah 1 jam.

\section{Proses Netralisasi}

Karbon aktif yang terbentuk dinetralkan dengan larutan $\mathrm{HCl} 0,5 \mathrm{~N}$ dan dicuci dengan aquades panas dan dingin sehingga tercapai $\mathrm{pH}$ 6,5. Selanjutnya karbon aktif dikeringkan di dalam oven selama 2 jam pada suhu $110{ }^{\circ} \mathrm{C}$.

\section{Uji Kualitas Karbon Aktif}

\section{Rendemen (ASTM, 1979 dan SNI, 1995)}

Karbon aktif yang sudah diperoleh terlebih dahulu dibersihkan, kemudian ditimbang.

$$
\text { Rendemen }(\%)=\frac{\text { berat karbon aktif }}{\text { berat bahan }} \times 100 \%
$$

\section{Kadar Air (ASTM, 1971 dan SNI, 1995)}

Sebanyak 5 gram sampel yang telah dihaluskan ditempatkan dalam cawan, kemudian dikeringkan dalam oven pada suhu $105{ }^{\circ} \mathrm{C}$ selama 3 jam hingga bobot konstan. Selanjutnya sampel didinginkan dalam eksikator selama 15 menit. Kemudian ditimbang beratnya.

$$
\text { Kadar air }(\%)=\frac{\text { penyusutan bahan }}{\text { gram sampel }} \times 100 \%
$$

\section{Kadar Abu Total (ASTM, 1971 dan SNI,1995)}

Sebanyak 5 gram sampel ditimbang didalam cawan, kemudian dikeringkan di dalam oven pada suhu $105{ }^{\circ} \mathrm{C}$ selama 1 jam sampai mencapai bobot konstan. Kemudian dipanaskan pelan-pelan diatas bara sampai asap berhenti mengepul. Setelah itu, dimasukkan ke dalam furnace dan diabukan pada suhu $650{ }^{\circ} \mathrm{C}$ selama 2 jam sampai terbentuk abu putih. Abu yang terbentuk dibasahi air suling, dikeringkan dengan penangas air, kemudian pada hot plate, kemudian diabukan kembali sampai dapat bobot konstan.

Kadar abu total $(\%)=\frac{\text { bobot abu total }}{\text { gram sampel }} \times 100 \%$

\section{Daya Serap Terhadap IOD (SNI, 1995)}

Ditimbang karbon aktif sebanyak 1 gram dan dimasukkan ke dalam erlenmeyer, selanjutnya di tambahkan dengan $25 \mathrm{ml}$ larutan iod monoklorida dan erlenmeyer ditutup dengan tutup yang telah dibasahi dengan KI, kemudian di kocok dengan hati-hati dan di simpan ditempat yang gelap selama $2 \mathrm{jam}$, kedalam erlenmeyer di 
tambahkan $10 \mathrm{ml}$ larutan kalium Iodida (KI) 20 $\%$ dan $150 \mathrm{ml}$ air suling, kemudian dikocok dan seterusnya dititrasi dengan larutan tiosulfat $0,1 \mathrm{~N}$.

\section{Daya Serap Terhadap Methylene Blue}

Karbon aktif diambil sebanyak 0,1 gram lalu ditambahkan larutan methylene blue 100 ppm sebanyak $20 \mathrm{ml}$ kemudian ditempatkan dalam erlenmeyer $50 \mathrm{ml}$ dan ditutup dengan aluminium foil, sampel diaduk menggunakan magnetik stirer selama 15 menit dan didiamkan selama 30 menit. Larutan hasil pengadukan disaring dan filtratnya dianalisis menggunakan spektrofotometri UVVIS pada panjang gelombang maksimum yang telah diperoleh. Absorbansi yang dihasilkan dari pengukuran UV-VIS dimasukkan dalam persamaan linear kurva standart untuk mengetahui konsentrasi akhir methylene blue yang telah diinteraksikan dengan karbon aktif. Jumlah methylene blue yang diserap oleh karbon aktif ditentukan berdasarkan perbedaan konsentrasi methylene blue sebelum dan sesudah penyerapan.

\section{HASIL DAN PEMBAHASAN}

Karbon aktif yang telah terbentuk dengan variasi suhu pemanasan diuji kualitasnyadengan menetukan nilai rendemen, kadar air, kadar abu, daya serap terhadap iod dan daya serap terhadap methylene blue.

\section{Rendemen}

Rendemen karbon aktif yang dihasilkan pada penelitian ini berkisar antara $(40,318-16,844) \%$. Rendemen yang tertinggi dihasilkan oleh karbon aktif yang dikarbonisasi pada suhu $300{ }^{\circ} \mathrm{C}$ yaitu $40,318 \%$, sedangkan rendemen yang terendah dihasilkan oleh karbon aktif yang dikarbonisasi pada suhu $600{ }^{\circ} \mathrm{C}$ yaitu $16,844 \%$. Nilai rendemen yang bagus adalah karbon aktif yang dikarbonisasi pada suhu $300{ }^{\circ} \mathrm{C}$, karena semakin tinggi nilai rendemen tersebut maka semakin banyak karbon aktif yang terbentuk. Jadi, hanya sedikit dari sampel yang teroksidasi pada proses karbonisasi.

Meningkatnya suhu karbonisasi juga cenderung mengakibatkan turunnya rendemen arang aktif yang dihasilkan. Hal ini disebabkan karena panas akan mempercepat laju reaksi antara karbon dengan uap air, sehingga semakin banyak karbon yang terkonversi menjadi $\mathrm{H}_{2} \mathrm{O}$ dan $\mathrm{CO}_{2}$ dan semakin sedikit karbon yang tersisa yang mengakibatkan rendemen arang aktif yang diperoleh sedikit[4]. Hal ini sesuai dengan teori kinetika yaitu semakin tinggi suhu reaksi yang digunakan, maka laju reaksi akan bertambah cepat.

\section{Kadar Air}

Penetapan kadar air bertujuan untuk mengetahui sifat higroskopis karbon aktif. Dari hasil penelitian ini kadar air yang dihasilkan berkisar antara (4,390-2,910) \%. Kadar air tertinggi dihasilkan oleh karbon aktif yang dikarbonisasi pada suhu $300{ }^{\circ} \mathrm{C}$ yaitu $4,390 \%$, sedangkan kadar air terendah dihasilkan oleh karbon aktif yang dikarbonisasi pada suhu $600{ }^{\circ} \mathrm{C}$ yaitu $2,910 \%$. Kadar air yang dihasilkan pada penelitian ini sudah memenuhi SNI yaitu maksimal 4,5\%.

Dapat dilihat dari hasil penelitian bahwa peningkatan suhu karbonisasi akan menyebabkan penurunan kadar air pada karbon aktif yang dihasilkan, dengan kata lain semakin tinggi suhu karbonisasi maka kadar air yang dihasilkan karbon aktif semakin rendah. Suhu karbonisasi mempengaruhi besarnya zat-zat volatile yang berpindah saat terjadi dekomposisi thermal. Jika semakin tinggi temperatur karbonisasi maka zatzat yang mudah menguap akan berkurang[5]. Kadar air yang tinggi dapat menurunkan mutu karbon aktif karena dapat mengurangi daya serap terhadap gas atau cairan [6].

\section{Kadar Abu}

Kadar abu yang dihasilkan pada penelitian ini berkisar antara $(1,920-2,730) \%$. Kadar abu tertinggi dihasilkan oleh karbon aktif yang dikarbonisasi pada suhu $300{ }^{\circ} \mathrm{C}$ yaitu $2,730 \%$, sedangkan kadar abu terendah dihasilkan oleh karbon aktif yang dikarbonisasi pada suhu $600{ }^{\circ} \mathrm{C}$ yaitu $1,920 \%$. Pada tabel diatas dapat dilihat bahwa Kadar abu yang dihasilkan pada penelitian ini sudah memenuhi SNI yaitu karbon aktif yang dikarbonisasi pada suhu $450{ }^{\circ} \mathrm{C}$ dan pada suhu karbonisasi $600{ }^{\circ} \mathrm{C}$. Kadar abu yang terkandung 
di dalam karbon aktif yang diperbolehkan menurut SNI yaitu 2,5\%.

Berdasarkan hasil yang diperoleh bahwa peningkatan suhu karbonisasi akan menyebabkan penurunan kadar abu pada karbon aktif yang dihasilkan[7]. Suhu karbonisasi berhubungan dengan besarnya energi yang dibutuhkan oleh makromolekul untuk memungkinkan terjadinya pemutusan ikatan hidrokarbon, sehingga kandungan karbon meningkat dan pengotor (kadar abu) semakin kecil. Semakin tinggi kadar abu maka semakin banyak pula kandungan bahan anorganik dalam bahan dan akan mengurangi daya serap karbon aktif, karena kandungan mineral yang terdapat dalam abu menyebar dalam kisi-kisi karbon aktif.

\section{Daya Serap Terhadap Iod}

Uji iod merupakan parameter untuk mengetahui kemampuan karbon aktif dalam menyerap molekul-molekul kecil dan zat dalam fase cair. Daya serap karbon aktif terhadap iod yang dihasilkan dalam penelitian ini berkisar antara $(235,273$ - 792,427) mg/g. Daya serap terhadap iod yang tertinggi dihasilkan oleh karbon aktif yang dikarbonisasi pada suhu $600{ }^{\circ} \mathrm{C}$ adalah $792,427 \mathrm{mg} / \mathrm{g}$, sedangkan daya serap terhadap iod yang terendah dihasilkan oleh karbon aktif yang dikarbonisasi pada suhu $300{ }^{\circ} \mathrm{C}$ adalah 235,273 mg/g. Daya serap terhadap iodium menurut SNI yaitu minimal $750 \mathrm{mg} / \mathrm{g}$. Daya serap terhadap iodium yang dihasilkan dari penelitian sudah memenuhi SNI yaitu karbon yang dikarbonisasi pada suhu $600{ }^{\circ} \mathrm{C}$ sekitar $792,427 \mathrm{mg} / \mathrm{g}$.

Menurut Pari et al, tinggi rendahnya daya serap karbon aktif terhadap Iodin menunjukkan banyaknya dimeter pori arang aktif yang

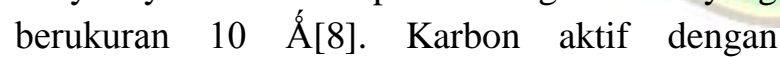
kemampuan menyerap iodnya tinggi berarti memiliki luas permukaan yang lebih besar dan juga memiliki struktur mikro dan mesoporous yang lebih besar. Rendahnya daya serap karbon aktif dapat disebabkan oleh kerusakan atau erosi dinding pori karbon dan juga menggambarkan sedikitnya struktur mikropori yang terbentuk dan kurang dalam. Semakin tinggi suhu karbonisasi maka semakin luas permukaan karbon aktif, sehingga daya adsorpsinya juga besar.

Daya Serap Terhadap Methylene Blue

Adsorpsi Methylene Blue telah banyak dilakukan untuk menentukan kapasitas adsorpsi karbon aktif. Penetapan ini bertujuan untuk mengetahui kemampuan karbon aktif untuk menyerap larutan berwarna dan menentukan luas permukaan pori karbon aktif.

Penentuan daya serap terhadap Methylene Blue dilakukan dengan menggunakan Spektofotometer UV-Visible pada panjang gelombang $665 \mathrm{~nm}$. Daya serap karbon aktif terhadap Methylene Blue yang dihasilkan dari karbon yang dikarbonisasi pada suhu $300{ }^{\circ} \mathrm{C}, 450$ ${ }^{0} \mathrm{C}$, dan $650{ }^{\circ} \mathrm{C}$, berkisar antara $(18,23719,925)$ $\mathrm{mg} / \mathrm{g}$. Daya serap karbon aktif terhadap Methylene blue yang tertinggi dihasilkan oleh karbon aktif yang dikarbonisasi pada suhu $600{ }^{\circ} \mathrm{C}$ yaitu $19,925 \mathrm{mg} / \mathrm{g}$, sedangkan daya serap karbon aktif terhadap methylene blue yang terendah dihasilkan oleh karbon aktif yang dikarbonisasi pada suhu $300{ }^{\circ} \mathrm{C}$ yaitu $18,237 \mathrm{mg} / \mathrm{g}$. Daya serap karbon aktif terhadap Methylene Blue yang dihasilkan dari penelitian ini belum memenuhi Standar Nasional Indonesia (SNI) yaitu 120 mg/g untuk serbuk karbon aktif dan $60 \mathrm{mg} / \mathrm{g}$ untuk butiran.

\section{KESIMPULAN}

Perbedaan suhu karbonisasi memberikan pengaruh terhadap kualitas karbon akif yang dihasilkan, semakin tinggi suhu karbonisasi, maka kualitas karbon aktif yang dihasilkan akan semakin baik, tapi suhu optimal untuk pembuatan karbon aktif secara kimia ini adalah suhu $600{ }^{\circ} \mathrm{C}$. Pada suhu $600{ }^{\circ} \mathrm{C}$ dihasilkan kualitas karbon aktif yang sudah memenuhi SNI. Nilai kualitas karbon aktif pada suhu $600{ }^{\circ} \mathrm{C}$ yaitu rendemen adalah 16,844, kadar air adalah 2,910 \%, kadar Abu adalah $2,210 \%$, daya serap terhadap Iodium adalah 792,427 mg/g, Sedangkan untuk Methylene Blue belum mencapai SNI, nilainya $19,925 \mathrm{mg} / \mathrm{g}$.

\section{DAFTAR PUSTAKA}

Widyastuti \& Sunardi. 2007. Karakteristik Karbon Aktif dari Alang-alang 
(Imperata) yang Dibuat dengan Cara Kimia, Jurnal Kimia dan Teknologi, Universitas SetiaBudi.

Prihandana, Rama dkk. 2008. Bioetanol Ubi Kayu Bahan Bakar Masa Depan. Jakarta: AgroMedia Pustaka.

Ikawati, Melati. Pembuatan Karbon Aktif dari Limbah Kulit Singkong UKM Tapioka Kabupaten Pati. Jurusan Teknik Kimia Fakultas Teknik Universitas Diponegoro. Sudradjat R., Anggorowati \& D. Setiawan. 2005. Pembuatan Arang Aktif dari Kayu Jarak Pagar (Jatropha curcas L.). Jurnal Penelitian Hasil/Hutan. Bogor: Pusat Litbang Hasil Hutan.

Jankowska, H., Swiatkowski, A., Choma, J. Active Carbon. 1991. Horwood. London.

Irmanto, Suyata. 2009. Penurunan kadar Amonia, Nitrit, dan Nitrat Limbah Cair Industri Tahu Menggunakan Arang Aktif Dari Ampas Kopi. Molekul, Vol. 4. No. 2: $105-114$
Windy Zamrudy. 2008. Pembuatan karbon Aktif Dari Ampas Biji Jarak Pagar (Jatropha Curcas Linn). Jurnal Teknologi Separasi, Vol. 1 No.2 - ISSN 1978-8789.

Pari, G. \& Hendra, Djeni. 2005. Pengaruh lama waktu aktivasi dan konsentrasi asam fosfat terhadap mutu arang aktif kulit kayu Acacia mangium. Jurnal Penelitian Hasil Hutan.(Bogor: Pusat Litbang Hasil Hutan)

Sembiring, Meilitia Tryana,dkk. 2003. Arang Aktif (Pengenalan dan Proses Pembuatannya). USU: Digital Library. Hal 1-9.

Petrus, Darmawan., Pembuatan Dan Karekterisasi Karbon Aktif Dari Kulit Ubi Kayu. Jurnal Kimia Dan Teknologi ISSN 0216-163. 